\title{
Rehabilitation as a Catalyst of Sustaining a Living Heritage: The Case of Souk Waqif in Doha, Qatar
}

\author{
Djamel Boussaa \\ Department of Architecture and Urban Planning, College of Engineering, Qatar University, Doha, Qatar \\ Email: DjamelB60@qu.edu.qa, DjamelB60@gmail.com
}

Received 29 June 2014; revised 28 July 2014; accepted 16 August 2014

Copyright (C) 2014 by author and Scientific Research Publishing Inc. This work is licensed under the Creative Commons Attribution International License (CC BY). http://creativecommons.org/licenses/by/4.0/ (c) (7) Open Access

\begin{abstract}
In recent years, mixed use urban fabric has become one of the new concerns of urban planners, urban designers, and architects. In many historic centers, urban diversity has been achieved spontaneously and it responded to the local needs of people at that time. However, today this urban space diversity is being seriously threatened. Souk Waqif, is one of the last surviving historic urban spaces in Doha. Due to the rapid urbanisation following the discovery of oil in 1939 and the beginning of its exportation in 1949, many houses in the Souk have been abandoned to become shelters for low income workers. Overcrowding, neglect, and lack of maintenance have resulted in more dilapidation of the souk and make it look like an urban slum in the heart of Doha. This paper attempts to assess the level of diversity of urban spaces existing in the souk and tries to identify if they form threats to its authenticity. This research is based on empirical research, onsite observations and interviews with the users. The outcomes of the survey and of site visits can inform us about the quality of the area and how it can be enhanced in the future.
\end{abstract}

\section{Keywords}

Urban Space, Diversity, Heritage, Tourism, Urban Conservation, Sustainability

\section{Introduction}

The growth of cultural tourism and its role in dispersing heritage to everyone are developing rapidly. According to the World Tourism Organization, natural and cultural heritage resources are and will remain as motivating factors for travel in the foreseeable future. According to the experts, people choose travel destinations where they can learn about traditional souks in their historic context. The balance that must be maintained is between 
visitor access and conservation needs (Medlik, 1991).

For a town to be sustainable, it must be viable to remain viable and it must change as circumstances change. If there is a desire to sustain life in the souks and not become fossilized, we must allow and even encourage change. Architecturally, a historic souk or area may appear delightful but economic activity is essential for its survival. Therefore, it is not only the preservation of the physical fabric that helps conserve its meaning, but its usage and function that enable it to withstand the rapidly changing urban dynamics. It is the activity and usage of these souks and areas that continues to make them meaningful artifacts in the present city and a strong vehicle to sustain its life and cultural identity (Zancheti, 1997).

Tourism is encouraged by the governments to obtain foreign currency. However, over-promotion of tourism can be disastrous. It can destroy the culture and the environment that people come to experience. Tourists do not leave a city untouched by their presence. The tourist subtly and sometimes drastically changes the character of a place. Residents in most cities need tourists for economic reasons and will change their cities and lives to serve them (Appleyard, 1979).

The merit of social intercourse between tourists and the local residents as a way towards fostering better understanding and good will between nations has been seen as a major benefit gained from tourism. While this is possible in countries where the flux of tourists is comparatively acceptable, in cases of mass tourism, tastes and habits have proven to be in many circumstances offensive to particular sectors of the local population.

Many other socio-cultural problems linked to tourism are related to the degree of intensity of tourism development. While it is difficult to measure, there is a relationship between tourism density and the growth of local resentment towards tourism. The flow of tourists into a region increases the densities at which people live and overcrowds the facilities which global visitors share with the host population. Therefore, overcrowding can reduce the value of the experience and may create additional strains for the local community (Urry, 1995).

\section{The City of Doha: Historical Background}

Doha, as shown in Figure 1, the capital of Qatar is the largest city with over $80 \%$ of the nation's population residing in Doha or its surrounding suburbs. It is also the administrative and economic centre of the country with a population of 1,670,389 in April 2010 (www.qsa.gov.qa). In 1825, the city of Doha was founded under the name of Al-Bida. The name used in Arabic ad-dawha, which might have been derived from "dohat"-Arabic name for bay or gulf-referring to the Doha bay area surrounding corniche. In 1820, Major Colebrook described it as following:

"Guttur-Or Ul Budee [Al Bidda] once a considerable town, is protected by two square Ghurries near the sea shore; but containing no fresh water they are incapable of defense except against sudden incursions of Bedouins. Another Ghurry is situated two miles inland and has fresh water with it. This could contain two hundred men. There are remaining at Uk Budee about 250 men, but the original inhabitants, who may be expected to return from Bahrain, will augment them to 900 or 1000 men, and if the Doasir tribe, who frequent the place as divers, again settle in it, from 600 to 800 men.” (Rahman, 2006).

Since its establishment, the old city of Doha was bombed about three times which explains the disappearance of a large number of its historic buildings and areas from the today urban landscape. First it was bombarded by the British vessel Vestal in 1821, then it was bombed again in 1841 and the village was completely destroyed in 1847 after a battle against $\mathrm{Al}$ Khalifas of Bahrain near Fuweirat, a village $25 \mathrm{~km}$ to the north of Doha.

$\mathrm{Al}$ Koot, the Turkish fort was built by the Ottomans in 1850 adjacent to Souk Waqif and near the main maqbara (cemetery) to control Doha and secure Souk Waqif from stealing, as most of the prominent traders lived in the souk (see Figure 2). A small force was garrisoned in the Koot, but left with the signing of the protection agreement of 1916 between Great Britain and Qatar. Subsequently Al Koot Fort was used as a prison for a time, and was home for the guards who patrolled the suq at night, a service paid for the traders who refused to pay taxes in the Souk. This confirms that Souk Waqif is well deep rooted in history.

During the early 20th century, when much of Qatar's economy depended on fishing and pearling, Doha had about 350 pearling boats. However, after the introduction of the Japanese cultured pearls in the 1930s, the whole region, including Doha, suffered a major depression and Qatar plunged into poverty. This forced many Qataris to migrate to the neighbouring countries.

Oill was discovered in 1939, but its exploitation was halted between 1942 and 1947 because of World War II and the Bahrain embargo. Oil exports and payments for offshore rights began in 1949 and this year marked a 


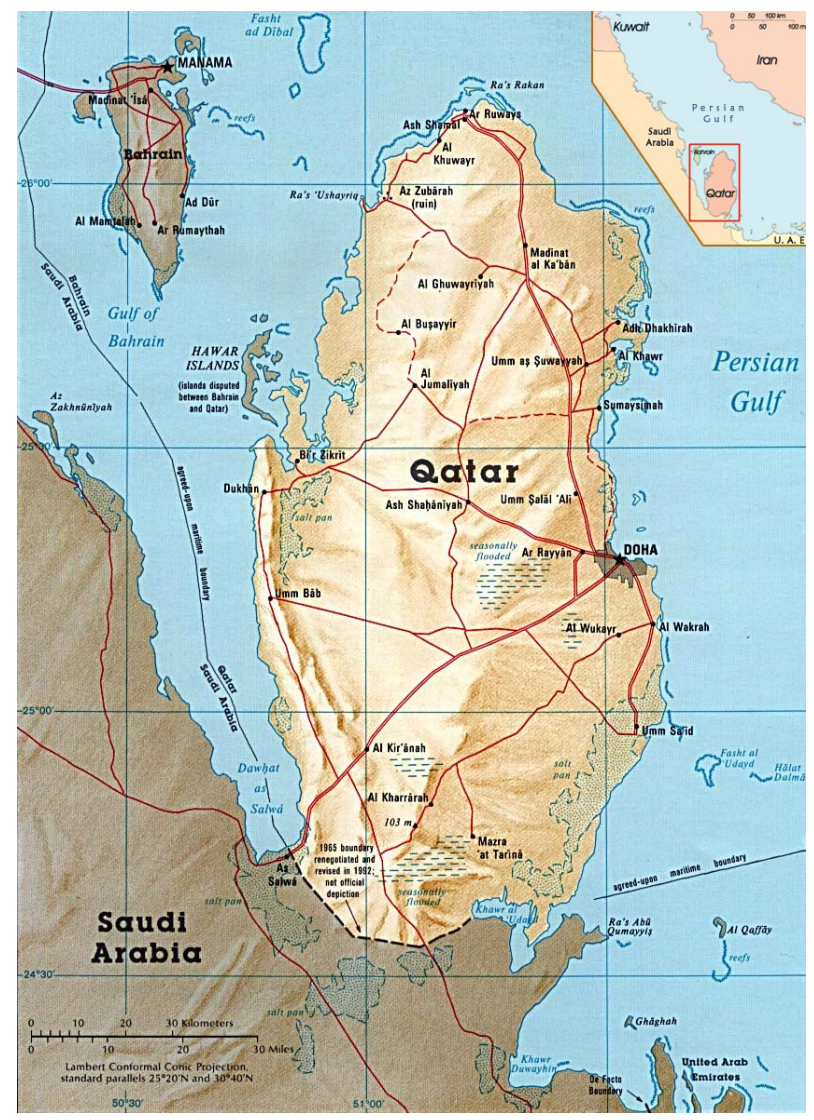

Figure 1. Map of Qatar.

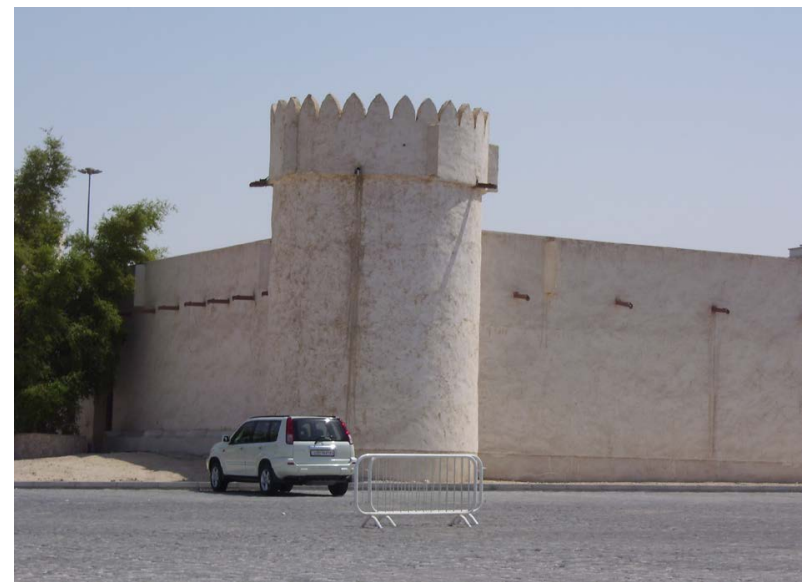

Figure 2. View of Al Koot fort in Souk Waqif.

major turning point in Qatar history. The early 1950s saw a cautious development of government structures and public services under the British tutelage. During the 1960s, new administrative centers sprang up to manage the vast revenues pouring from oil. In 1969, the Government House was opened and today it is considered as one of Qatar's most prominent landmarks. Following the withdrawal of the British, the State of Qatar declared its independence on September 3, 1971. Doha as the capital of the new state, attracted thousands of foreign experts and workers in the construction and engineering, health and education sectors.

Since then, Doha has seen the most extraordinary expansion in international banking, sporting and tourism activities, as evidenced by the many modern towers, malls, hotels and seats of power scattered throughout the 
city. In addition, huge developments like the Pearl, a whole commercial, residential, tourist and leisure complex has been developed beyond the West Bay area. As shown in Figure 3, the physical development of Doha and the various conurbations of the peninsula have been accompanied by extensive preparatory work, which led in many occasions to the destruction of historic buildings and areas. During the early years following independence, there was a national pride in the redevelopment with demolition being seen as a necessary process. Table 1 shows the major events that happened in Qatar and which formed the basis of developing diverse spaces in the old city.

\section{Souk Waqif: From Survival to Revival}

\subsection{Souk Waqif: Past and Present}

As shown in Figure 4, located behind the Corniche, off Grand Hamed Street, Souk Waqif is a down town hub of traditional architecture, handicrafts and folk art, and was once a weekend trading area for the Bedouin. The origins of the Souk date from the time when Doha was a village and its inhabitants gathered on the banks of the Msheirib wadi (river) to buy and sell goods. Waqif means in Arabic (standing); it refers to the merchants and inhabitants who were obliged to do their businesses by standing because of the water flooding on both sides of the Wadi, and pouring to Al Kharis area in the souk before reaching the cornice (Boussaa, 2010).

Souk Waqif is a maze of alleyways linking a wide area of various urban spaces. It consists of separate sections selling perfumes and traditional forms of Qatari national dress, luggage, tools, general hardware and gardening equipment; tents and camping equipment; kitchenware, spices, traditional sweets, rice, nuts, and dried fruits. This souk is famous for selling traditional garments, local Qatari clothes, handicrafts and souvenirs. It is also home to tens of restaurants serving a wide variety of cuisines from all over the world.

Within the 21st century, this traditional market, enlarged to house three major shopping facilities. They consist of areas for whole sale and retail, mainly for food supplies; including dates and rice. Small shops sell handycrafts, sewing and cloth and the last area consists of an outdoor free market. The idea of shopping experience with these old shops was intimate with outdoor displaying and selling process, keeping the indoor area as a storage facility (see Figure 5).

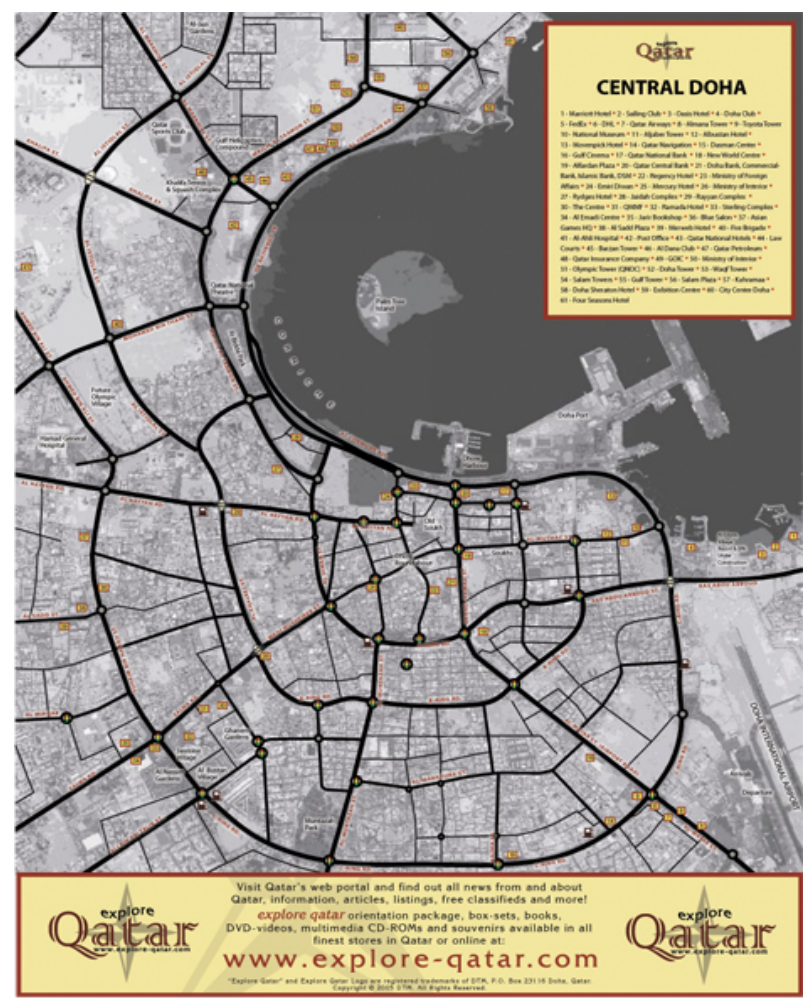

Figure 3. Development of the Doha central area. 
Table 1. Major historical events in Qatar.

4000 BC Ubaid pottery from Mesopotamia found in Qatar is thought to be the world's earliest evidence of international trade.

3000 - 1000 BC Qatar flourishes as a trading port between Mesopotamia and the Indus Valley.

2nd Century AD Greek geographer identifies “Qatara” on his map of the Arab world.

628 Qatar is one of the first civilizations to convert to Islam.

1515 The country comes under Portuguese influence.

1847 Sheikh Mohammed bin Thani, predecessor of the current ruling family, relocates its base to Doha.

1850 Three Bedouin tribes, the ancestors of the majority of contemporary Qataris, moved to the peninsula in search of fresh water.

1868 Treaty with Britain recognizes Qatar’s independence from Bahrain.

1893 Sheikh Qassim bin Mohammed Al Thani, the founder of the modern state of Qatar, defeats Ottoman forces.

1940 Oil is discovered at Dukhan.

19713 September, Qatar becomes an independent state.

1973 Qatar University

1975 Qatar National Museum

$1991 \quad$ Production of gas begins in Qatar's North Field media in the region.

2008 Qatar National Research Fund

2009 Qatar Science and Technology Park opens; an important step in realizing a knowledge-based society

2012

New Doha International Airport will open, effectively tripling Qatar’s international passenger capacity to meet growing demand.

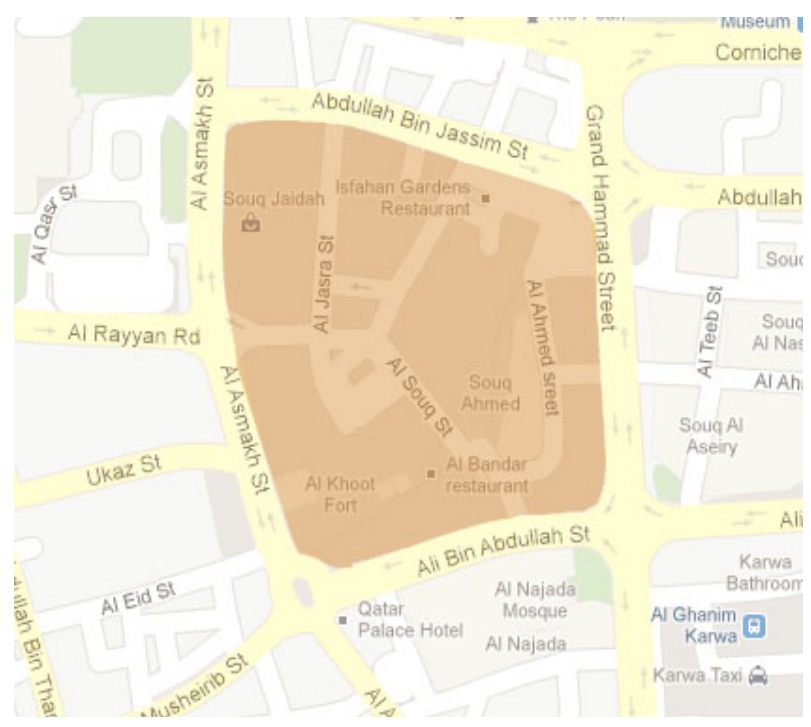

Figure 4. Strategic location of Souk Waqif in the heart of Doha. 


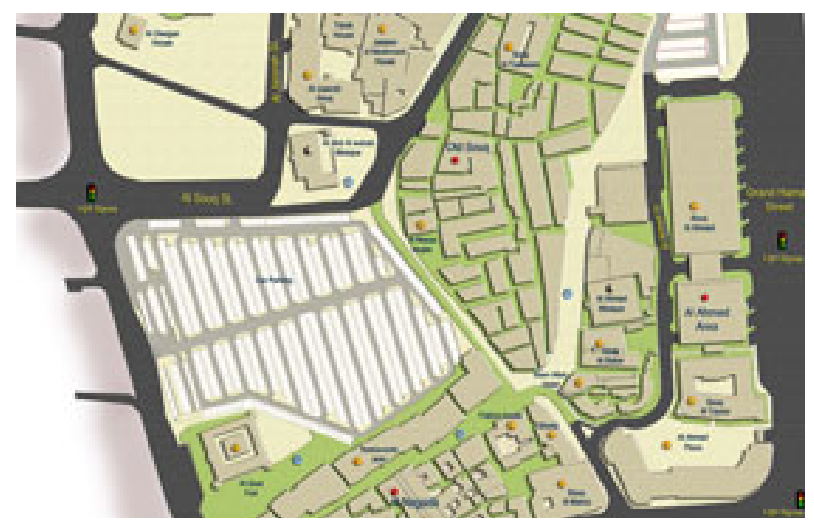

Figure 5. Site plan of Souk Waqif showing the diverse urban spaces.

During the early years following independence, the souk fell into disrepair and decay while alien modern structures replaced the old shops. At this stage, the Souk area was invaded by inhuman buildings, of dense shops frontage, crowded entrances, and clash of functions. The renewal process was randomly done by the individual shop keepers with the absence of a unifying vision among the Souk. Adaptation to enhance the unit quality was merged with the desire to create the modern shopping experience by enlarging the shop area and creating the transparent glass steel facades. This has been accompanied by adding air conditioning window type units in a way that disrupted and harmed the visual quality among the souk corridors (see Figure 6).

In the souk, pedestrian alleyways were covered with tinned sheets as a quick, cheap and available solution to create the needed shade for the shoppers. However, the use of these metallic roofs was insufficient in a way that it increased heat gain and solar absorption, creating a condensed humid air unpleasing spaces for both visitors and shopkeepers. The Simple plain environmental architecture of Qatar had been transferred in to a dense hybrid complex, taking off the human spirit of Qatari architecture, as well as, its native inhabitants. The influx of Asian workers reached the zenith, creating crowded conditions and forced the local owners and inhabitants to search for better living alternatives elsewhere (see Figure 7(a) \& Figure 7(b)). This resulted in transferring old memorial Souk into a native deserted city center.

\subsection{Souk Waqif Rehabilitation Project}

The private engineering Bureau of the Amiri Diwan launched a rehabilitation project of Souk Waqif in 2003. Since most of the buildings in Souk Waqif were privately owned, the government bought these buildings from their owners in order to start the work. After a detailed survey it has been found that $2 / 3$ of the buildings were original, however only one third of them had been demolished and replaced by modern structures (Mohamed Ali, 2008). The strategy adopted in conserving Souk Waqif consisted of the following measures and actions:

- restoration of the old part;

- reconstruct the old ones whenever possible;

- modernize the local infrastructure;

- remove all the advertisment signs around.

The revitalization project was based on a thorough study of the history of the market and its buildings. The project aimed at stopping the dilapidation of the historic structures and removing the inappropriate alterations and additions that have been added. The Private Engineering Bureau attempted to revive the memory of the place. To achieve this, a number of new alien buildings were demolished. Metal sheets on roofs were replaced with traditional roofs of danjall and bamboo with a binding layer of clay and straw. In most cases, traditional strategies to insulate the buildings against the extreme heat have been applied. Glass doors have been replaced by the traditional wooden doors and windows.

After seven years of work the dream of rehabilitating Souk Waqif has become a reality; it has recreated a living heritage in the middle of a global environment. The souk has strengthened its status as a major hub for Qatari people, local expatriates and international visitors. At present, people go to Souk Waqif for shopping, entertainment and gazing around due to its diverse and mixed used urban spaces and activities. With the existing 


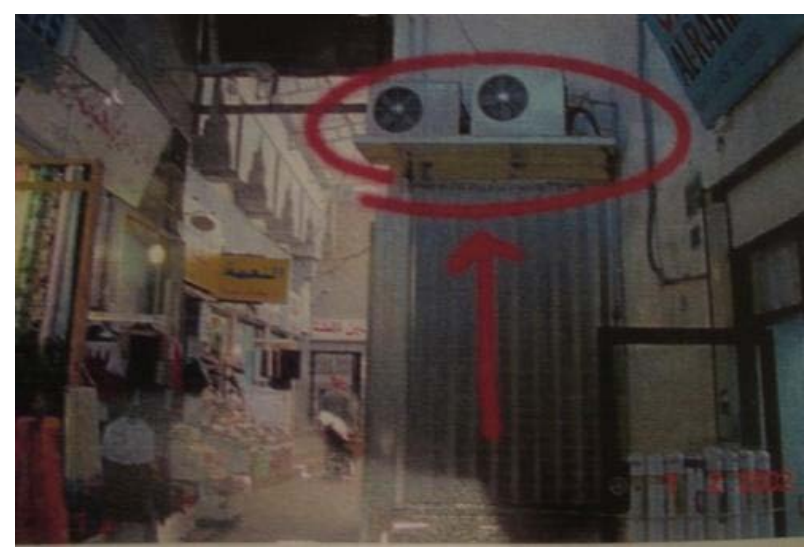

Figure 6. Inappropriate insertion of air conditioning units into the shop walls.

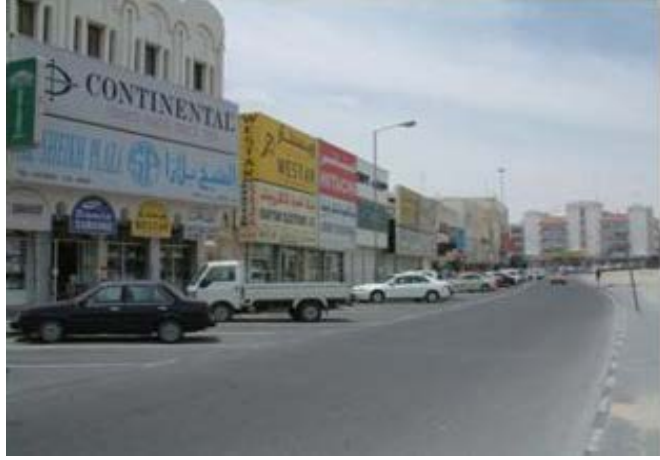

(a)

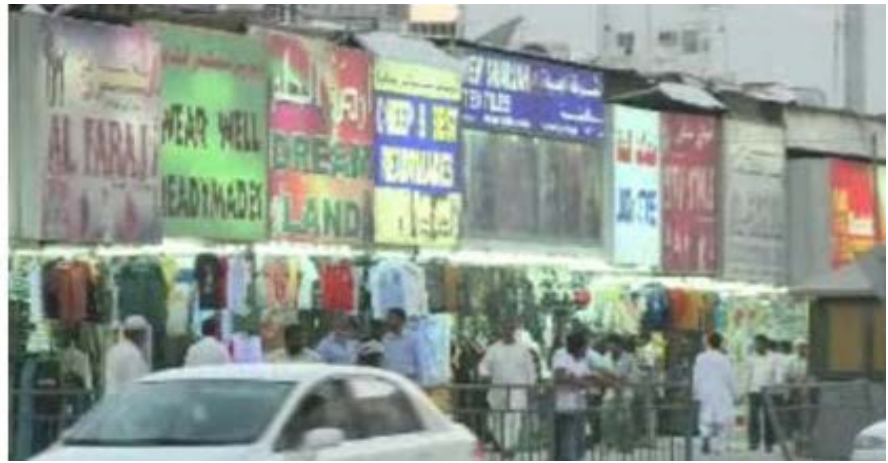

(b)

Figure 7. Overcrowding of the souk was a major threat to its survival.

art center Souk Waqif is now considered one of the top tourist destinations in Qatar. In addition to tourism, entertainment and leisure, Souk Waqif has become a major hub for art galleries and workshops, hosting several art galleries and local concerts during holidays and special celebrations. The Center combines a selection of small artistic shops with a number of exhibition rooms laid out around a long narrow courtyard (see Figure 8).

Some new features have been also introduced, such as a sophisticated lighting system that illuminates the market's streets. In complete contrast to the fake heritage theme parks that are mushrooming in the region, Souk Waqif is both a traditional open-air public space that is used by shoppers, tourists, merchants and residents alike, and a day and night living market.

Currently the souk enjoys its last phase of rehabilitation project; Souk Waqif is a major tourist place to explore. There has been a Souk on this site for centuries, as this was the spot where the Bedouin would bring their sheep, goats and wool to trade for essentials. It grew into a scruffy warren of concrete alleyways in recent years. Now its tourist potential has been recognized and it's been cleverly rehabilitated to reflect the soul of an authentic Qatari Souk, with mud-rendered shops and exposed timber beams. Despite the fairly "Densification” of the area, the chief business of the Souk continues unabated and it remains one of the most bustling and thriving traditional markets in the Gulf (see Figure 9).

\subsection{Souk Waqif Today}

After seven years of rehabilitation and refurbishment work, Souk Waqif has increased the local inhabitants' pride towards their past. Souk Waqif has become a famous tourist attraction for the fusion of traditional and modern elements, among its 164,000 $\mathrm{m}^{2}$, Souk Waqif houses 500 ancient shops varying between pottery, traditional swords, daggers, hand crafts, jewelers and copper utensils. Facilities had been distributed within two major zones, the old Souk reached by Abdulla Bin Thani Street and Grand Hamad Street, and the new restaurant 


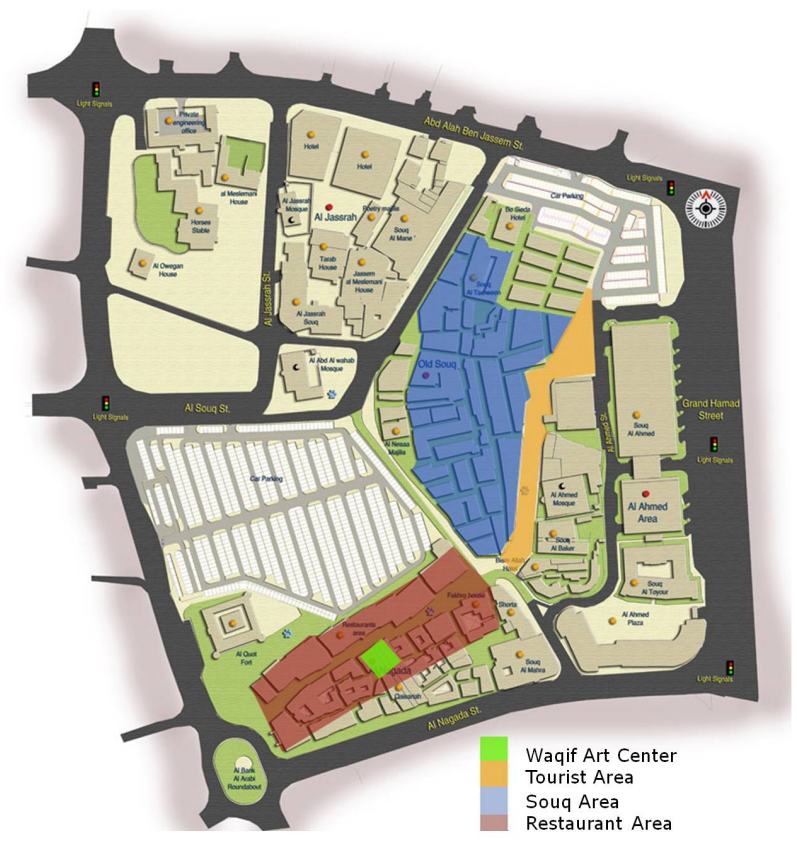

Figure 8. Diversity of spaces in Souk Waqif, ensures its livability and sustainability.

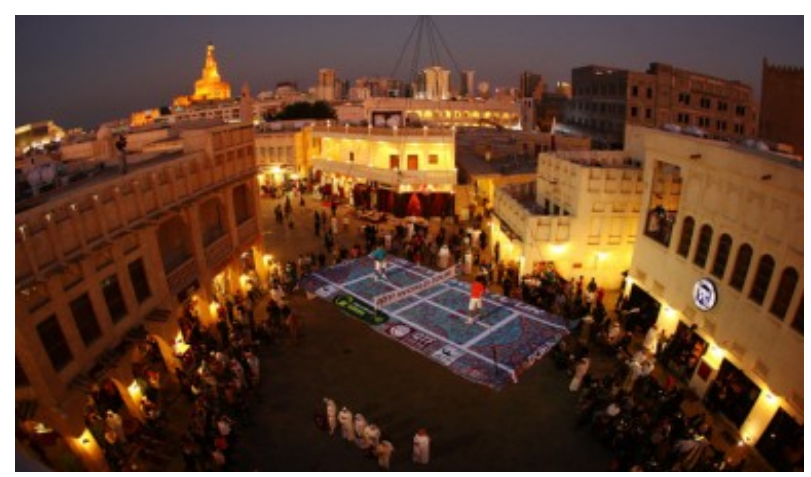

Figure 9. Souk Waqif, a living heritage day and night and a major landmark.

area taking a place over Al-Najada old Souk and reached from Al-Najada Street. The old Souk along alleys, comprise colorful ground spices displayed in boxes, sacks and huge tubes. In addition, there is space for gold, clothes, and animals (see Figure 10).

The second type of restaurants has public setting which is designed to be a sample of the old Qatari's setting. These restaurants offer all types of Qatari meals. It is surprising that these places attract more foreign tourists than the fancy restaurants. The intermediate area between traditional hand shops, Waqif Art Center and the traditional majles settings is the busiest area along the whole Souk (see Figure 11). All services are distributed within a walking distance where vehicular circulation is kept outside the pedestrian zone. The parking area is considered as the main issue. The increased parking capacity can be seen in the following plan, where 410 parking lots were provided in 2003, which increased to 440 in 2007 and 590 parking lots, distributed in two sides in 2009.

\section{Epilogue}

Urban conservation does not necessarily mean preserving a building but reviving its spirit and life. It means being flexible enough to adapt the objectives of rehabilitation to the needs of modern living while respecting the 


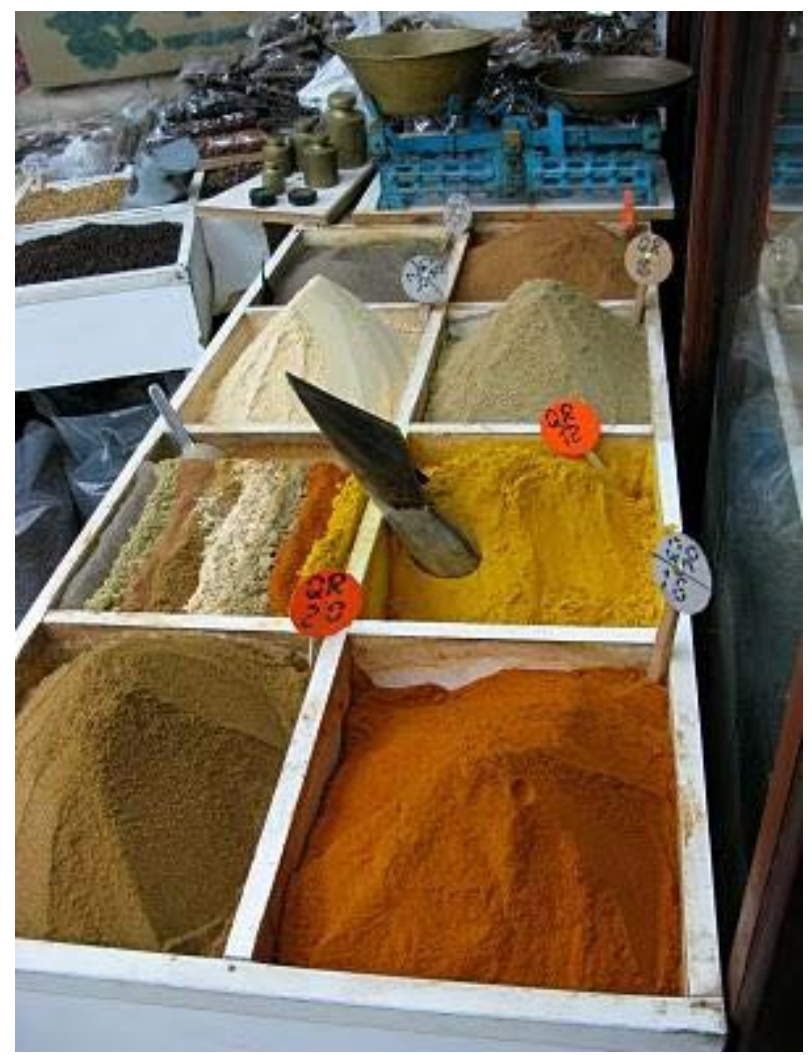

Figure 10. Souk Waqif, the spices corner.

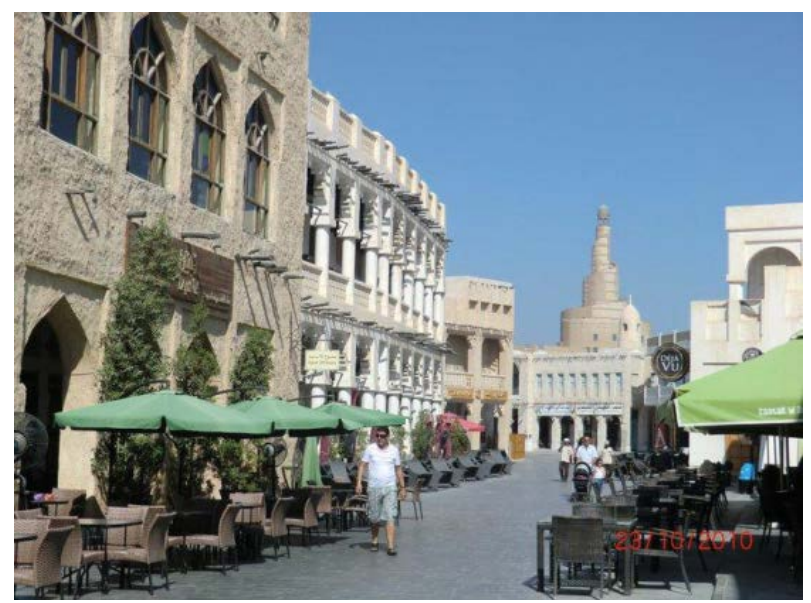

Figure 11. The bustling restaurants area in Souk Waqif.

local community values. Diversity of public areas is important and essential as they ensure the sustainability of a living heritage and to the way in which people interact and identify with their locality. It is therefore, paramount that rehabilitation includes a variety of public areas to strengthen people's sense of belonging (Dix, 1995).

The situation of historic souks in the Gulf is particularly alarming. The souk is both the content and container, as it were, of heritage. Heritage tourism is an important and desired activity for both visitors and hosts. The challenge to cultural resource managers is to mitigate the amount of damage that visitors can cause to sites.

Rehabilitation of Souk Waqif is a successful example of sustaining souks and markets in Qatar and the Gulf. After long years of dilapidation and neglect, it has become a sustainable living heritage in the heart of Doha. Despite the threats of the expansion of high rise developments around the souk, it is a strong statement and 
message that a souk can survive despite the proliferation of laborious shopping malls around. Due to the efforts undertaken to rehabilitate this souk during the period 2004-2007, the Aga khan Award for Islamic Architecture in November 2010 pre-selected this souk from the 400 entries to compete amongst 19 nominees for the 11th Cycle of Aga Khan Award for Architecture (www.akdn.org/Architecture/awards).

\section{References}

Appleyard, D. (1979). The Conservation of Cities. London: The MIT Press.

Boussaa, D. (2010). Interview with Mr. Mohamed Ali Abdulla, Souk Waqif, Doha.

Dix, G. B. (1995). The Re-Use of Buildings in Historic Towns: A Coincidence of Economic and Cultural Activities. Ekistics, 267-272.

Medlik, S. (1991). Managing Tourism. Oxford.

Mohamed Ali, A. (2008). Souk Waqif, Sihr Al Turath Wa Asalatih. Unpublished Proceedings of the Symposium on Follklore in the State of Qatar. Doha, 12-14 February 2008.

Rahman, H. (2006). The Emergence of Qatar: The Turbulent Years 1627-1916. London: Routledge.

Urry, T. (1995). Consuming Places. London: Routledge.

Zancheti, S. M., \& Jokillehto, J. (1997). Values and Urban Conservation Planning: Some Reflections on Principles and Definitions. Journal of Architectural Conservation, 37-51. 
Scientific Research Publishing (SCIRP) is one of the largest Open Access journal publishers. It is currently publishing more than 200 open access, online, peer-reviewed journals covering a wide range of academic disciplines. SCIRP serves the worldwide academic communities and contributes to the progress and application of science with its publication.

Other selected journals from SCIRP are listed as below. Submit your manuscript to us via either submit@scirp.org or Online Submission Portal.
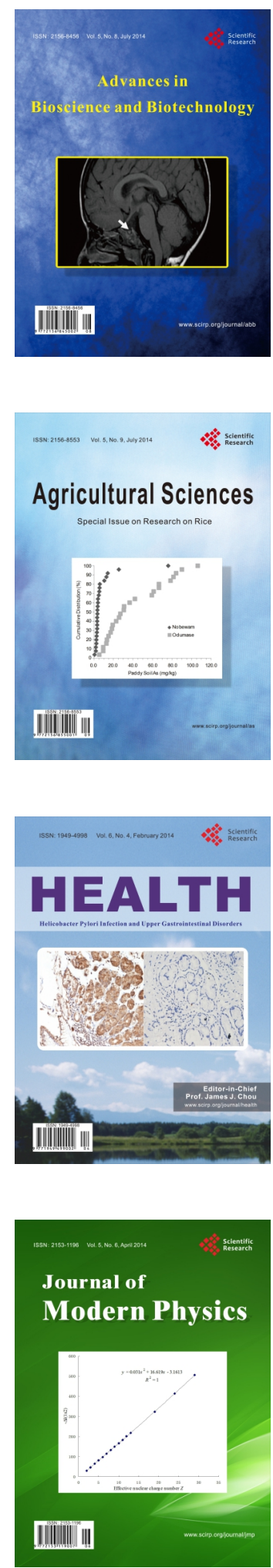
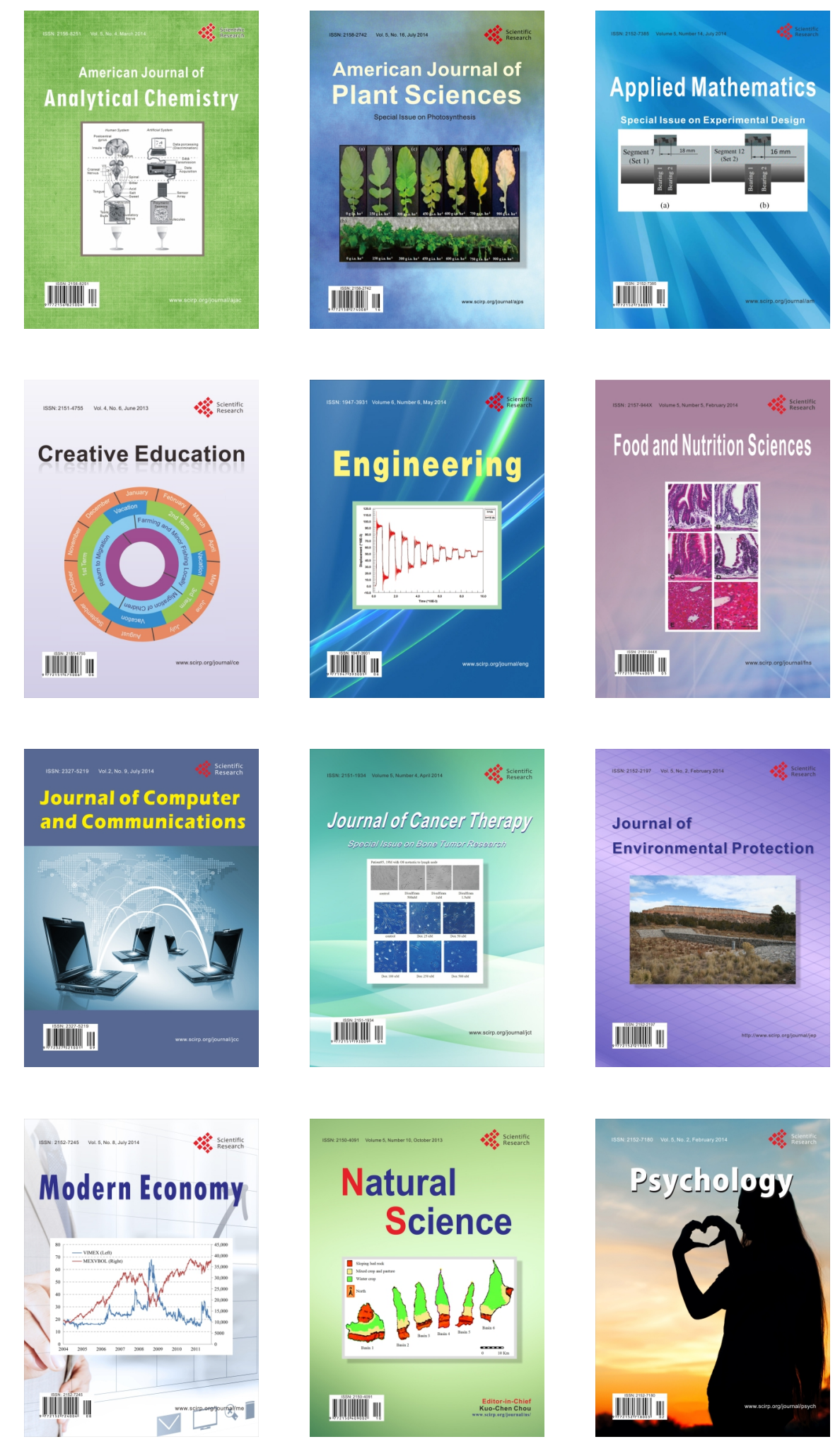